\title{
Seasonal variation of biotic and abiotic parameters in parallel neotropical fishponds
}

\author{
Sipaúba-Tavares, LH. *, Seto, LM. and Millan, RN. \\ Centro de Aquicultura, Univ. Estadual Paulista - UNESP, Via de Acesso Prof. Paulo Donato Castellane, \\ s/n, CEP 14884-900, Jaboticabal, SP, Brazil \\ *e-mail: sipauba@caunesp.unesp.br
}

Received: October 10, 2012 - Accepted: January 22, 2013 - Distributed: February 28, 2014

(With 5 figures)

\begin{abstract}
The present study was carried out to evaluate the phytoplankton community and water quality in four parallel fishponds (FP1 to FP4) during one year. Some abiotic parameters of water column and phytoplankton was sampled in four sites, one in each fishpond. Similarity analysis showed that FP2 fishpond was markedly different for the others ponds with regard to phytoplankton community. Conductivity, orthophosphate, temperature, TSS and hardness parameters were significantly different $(\mathrm{p}<0.05)$ between fishponds and all limnological parameters were significantly different $(\mathrm{p}<0.01)$ among period (months). Organic matter and phosphorus of the sediment were significantly different $(p<0.01)$ only among fishponds. In current study Chlorophyceae and Bacillariophyceae occurred in most months. Cyanobacteria density in April and May was higher in all fishponds, at FP3 represented 71.4\% in April and FP1 represented 78.7\% in May of total reported, with chlorophyll- $a$ content lower than $41 \mathrm{mg} . \mathrm{L}^{-1}$. The physical and chemical parameters of fishponds water constituted relations between the parameters and algae occurrence. The present study however, indicated that Cyanobacteria was more frequent in the fishponds after the fish grow-out period (April), and the water quality should be monitored more frequently in this period, due to the high total phosphorus, orthophosphate and chlorophyll- $a$ contents.
\end{abstract}

Keywords: algae, aquaculture, physical and chemical parameters, water quality.

\section{Variação sazonal dos parâmetros bióticos e abióticos em tanques de piscicultura com disposição paralela de região neotropical}

\begin{abstract}
Resumo
O presente estudo avaliou durante um ano a comunidade fitoplanctônica e os fatores abióticos da água de quarto tanques de piscicultura (FP1 ao FP4) com disposição paralela. Alguns fatores abióticos da água e do fitoplâncton foram amostrados em quarto pontos, localizados um em cada tanque de piscicultura. Análise de similaridade mostrou que o tanque de piscicultura FP2 foi diferente dos outros tanques em relação a comunidade fitoplanctônica. Condutividade, ortofosfato, temperatura, STS e dureza foram diferentes $(p<0,05)$ entre tanques e todas as variáveis limnológicas variaram entre o período de estudo $(\mathrm{p}<0,01)$. Matéria orgânica e fósforo do sedimento variaram $(\mathrm{p}<0,01)$ somente entre os tanques. Chlorophyceae e Bacillariophycea estiveram presentes em todos os meses amostrados. Em abril e maio foi observada elevada densidade de Cyanobacteria em todos os tanques sendo que no FP3 representou 71,4\% em abril e no FP1 78,7\% em maio do total encontrado, com teor de clorofila- $a$ abaixo de 41 mg.L. ${ }^{-1}$. Os parâmetros físico-químicos da água dos tanques de piscicultura apresentaram relação com a ocorrência do fitoplâncton nestes sistemas. Os resultados deste estudo indicaram a maior frequência de Cyanobacteria no período após a engorda de peixes (abril) necessitando maior monitoramento da qualidade da água devido aos altos teores de fósforo total, ortofosfato e clorofila- $a$ observados neste mês (abril)
\end{abstract}

Palavras-chave: alga, aquicultura, variáveis físicas e químicas, qualidade da água.

\section{Introduction}

Fishponds are dynamic ecosystems characterized by shallowness and continuous water flow, which directly affect both limnological variables throughout the day. The spatial and seasonal impact of fishponds on the water column is due to the high fish density and artificial regimes. The water quality is identified in terms of its biotic and abiotic parameters. In open artificial systems, such as fishponds, the physical, chemical and biological variables are highly affected by environmental conditions and management.

The physical and chemical parameters are used to evaluate the water quality of fishponds the results are responses to the rational use of water in the fishponds 
(Sipaúba-Tavares et al., 2010). However ecological water quality is defined by biological parameters because the composition of aquatic communities is reflected by the sum of all influencing or disturbing factors (Kopp et al., 2012).

Diversity of the plankton population is fairly dependent on water quality, climatic factors and management in fishponds that constantly receive large nutrient loads (feed, fertilizing, fish waste) which contribute towards algal growth (Sipaúba-Tavares et al., 2011). The abundance and composition of algae may be very useful indicators of water quality, since they reflect environmental conditions. Any environmental change within the fishpond may to cause, relevant repercussion on this community.

The variation of water quality and natural food (plankton) are strongly affected by fish density, or rather, when a lower biomass of phytoplankton occurs, available nitrogen and phosphorous in the water column are less. Since nutrients in the added fertilizers integrate the plankton biomass and later the trophic chain, fish biomass increases, coupled to subsequent high growth of fish production (Vega et al., 2007). Even if fish do not directly feed on the plankton, the community needs adequate water quality conditions so that biomass may remain at acceptable levels, without blooms or any toxin release in the water. These latter conditions are highly common in eutrophic systems such as fishponds.

The release of nutrients by fishponds is a continuous process through the year, reaching maximal values during the summer when high water temperature imposes the need for higher feeding rates (Neofitou and Klaoudatos, 2008).

Nutrients supply and its ratios have a decisive effect on the species composition of phytoplankton because different algal species have different nutrient requirements.
Differences in the phytoplankton biomass and composition have been found in ponds with different trophic status (Zhong et al., 2011).

The aim of this study was to evaluate the effects of the seasonal variation of biotic and abiotic parameters in four parallel fishponds with the same fishery management and fish stock density.

\section{Material and Methods}

\subsection{Area and fish management}

The study was carried out at the aquaculture farm $\left(21^{\circ} 15^{\prime} \mathrm{S}\right.$ and $\left.48^{\circ} 17^{\prime} \mathrm{W}\right)$ in four parallel fishponds (FP1 to FP4) with continuous water flow and $5 \%$ a daily volume exchange. Water supply comes from the others ponds up to the parallel fishponds and channeled to these fishponds by underground tubes. The surface area of fishponds is $45 \mathrm{~m}^{2}$ and their mean depth $1.50 \mathrm{~m}$ (Figure 1). The fishponds were populated with "pacu" fries (Piaractus mesopotamicus) and "tambaqui" fries (Colossoma macropomum), at a density of $0.15 \mathrm{~kg} . \mathrm{m}^{3}$. Fish were fed floating pelleted feed with $30 \%$ crude protein three times a day, at $3 \%$ weight.day ${ }^{-1}$.

\subsection{Sampling sites and physical and chemical data}

Physical and chemical parameters were recorded at surface sample $(0.10 \mathrm{~m})$ using a $1 \mathrm{~L}$ Van Dorn bottle, monthly during twelve months. Water samples were collected at one site in each fishpond (FP1 to FP4) (Figure 1). Temperature, $\mathrm{pH}$, dissolved oxygen and conductivity were measured using a multi-probe Horiba U-10. Total phosphorus, orthophosphate, nitrite, nitrate, and ammonia were quantified spectrophotometrically according to Golterman et al. (1978) and Koroleff (1976). Chlorophyll- $a$

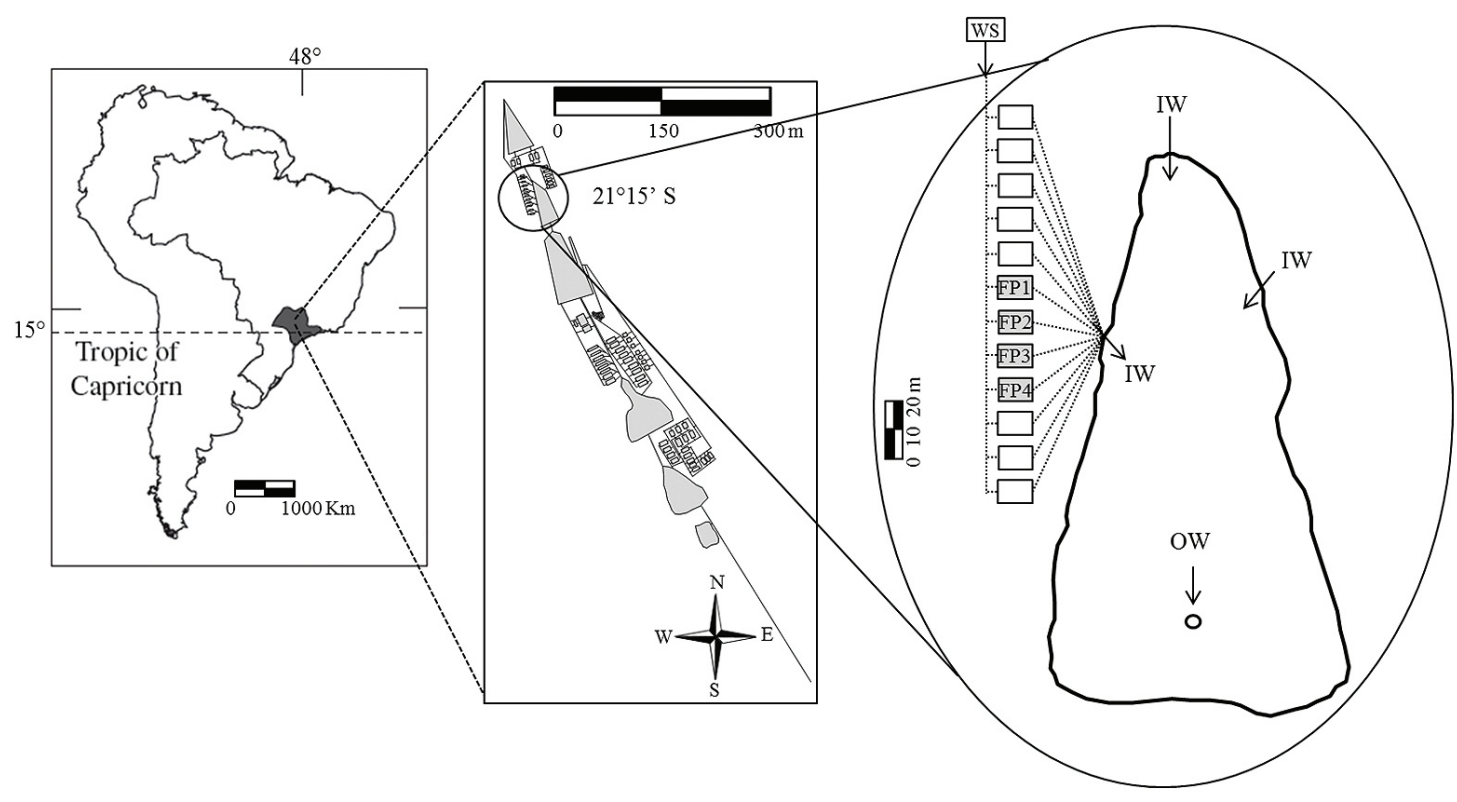

Figure 1. Cross-section of fishponds studied, where: FP1 to FP4 = fishponds, IW = inlet water, OW = outlet water, WS = water supply. 
was extracted with $90 \%$ alcohol and quantified at 663 and $750 \mathrm{~nm}$ (Nusch, 1980). Hardness, total suspended solids (TSS) and 5-day biochemical oxygen demand $\left(\mathrm{BOD}_{5}\right)$, was determined according to Boyd and Tucker (1992). Alkalinity and bicarbonate contents were determined according to Mackereth et al. (1978). Water transparency was estimated by a Secchi disk and sediment samples were undertaken for phosphorus and organic matter (OM) according to Andersen (1976). Analyses were performed immediately after sampling or samples were duly stored under refrigeration.

\subsection{Phytoplankton}

Phytoplankton composition was analyzed only in surface samples $(0.10 \mathrm{~m})$. Phytoplankton samples were taken by a $1 \mathrm{~L}$ Van Dorn bottle from each fishpond, monthly during twelve month, immediately filtered with $25 \mu \mathrm{m}$ of mesh nets and preserved in Lugol iodine solution. The net samples were observed in an optical microscope (200 X magnification) for preliminary taxonomical identifications. Samples for the quantitative analysis of the phytoplankton were collected with a Van Dorn bottle, fixed with $1 \%$ Lugol iodine solution and stored in ambar glass jars. Sub-samples were placed in sedimentation in Sedgewick-Rafter chamber during 30 minutes. After sedimentation the organisms (cells, colony and filaments) were counted using a Leica-Leitz microscope (APHA, 1998) and enumerated in 100 fields. At least 200 cells of the most frequent species or genus were counted $(p<0.05$; Lund et al., 1958). Frequency of occurrence was estimated for total phytoplankton organisms were divided into three categories: constant ( $50 \%$ or above); common (between $10 \%$ and 50\%) and rare (between $1 \%$ and 10\%) (Sampaio et al., 2002).

\subsection{Statistical analysis}

Analysis of variance (ANOVA) was used to evaluate differences among fishponds and among months, and their interactions. When a significant differences was detected, Fisher LSD (Least Square Differences) test was used post-hoc comparisons. All tests of significance were made at $\mathrm{p}=0.05$. The statistical analyses were carried out by Statistica 8.0 (StatSoft Inc, 2007). Fishponds were grouped by cluster analysis (un-weighted pair group average linkage, UPGMA) based on the Bray Curtis index, using abundance $\log _{10}(x+1)$ transformed data of all phytoplankton (Magurran, 1989).

\section{Results}

All limnological parameters of water column were significantly different $(\mathrm{p}<0.01)$ between months, but only orthophosphate, conductivity, TSS, temperature and hardness were significantly different $(\mathrm{p}<0.05)$ among fishponds (Table 1). An increase of total phosphorus, orthophosphate, and chlorophyll- $a$ was observed among November to April (Figures 2 and 3). The highest values of chlorophyll- $a$ was recorded among March and April and nitrate was lowest in these months varying between 99 to $250 \mathrm{mg} . \mathrm{L}^{-1}$ (Table 1; Figure 2).

Temperature was directly affected by local climatic conditions, with low values in July (winter) and high ones from December to March (summer) (Table 1; Figure 3). A sharp fall in dissolved oxygen concentrations occurred in October. This fact coincided with high ammonia contents in October varying between 76 and $155 \mathrm{mg} . \mathrm{L}^{-1}$; high water transparency varying between 125 to $150 \mathrm{~cm}$

Table 1. Physical and chemical variables of water samples, phosphorus $\left(\mathrm{P}_{\text {sed }}\right)$ and organic matter $\left(\mathrm{OM}_{\text {sed }}\right)$ in the sediment of the four fishponds (FP1 to FP4) during the studied period (Mean \pm standard deviation).

\begin{tabular}{|c|c|c|c|c|c|c|}
\hline \multirow{2}{*}{ VARIABLES } & \multicolumn{4}{|c|}{ FISHPONDS } & \multicolumn{2}{|c|}{ ANOVA } \\
\hline & FP1 & FP2 & FP3 & FP4 & Sites & Months \\
\hline Nitrate $\left(\mu \mathrm{g} . \mathrm{L}^{-1}\right)$ & $269.3 \pm 161.9$ & $261.3 \pm 171.6$ & $269.6 \pm 144.3$ & $284.5 \pm 170.2$ & $\mathrm{p}>0.05$ & $\mathrm{p}<0.01$ \\
\hline Nitrite $\left(\mu \mathrm{g} . \mathrm{L}^{-1}\right)$ & $3.1 \pm 1.5$ & $3.8 \pm 2.8$ & $4.1 \pm 3.2$ & $3.4 \pm 1.7$ & $\mathrm{p}>0.05$ & $\mathrm{p}<0.01$ \\
\hline Ammonia $\left(\mu \mathrm{g} . \mathrm{L}^{-1}\right)$ & $54.3 \pm 34.0$ & $43.0 \pm 27.5$ & $70.2 \pm 50.1$ & $53.0 \pm 40.8$ & $\mathrm{p}>0.05$ & $\mathrm{p}<0.01$ \\
\hline Total Phosphorus $\left(\mu \mathrm{g} . \mathrm{L}^{-1}\right)$ & $63.5 \pm 38.4$ & $71.9 \pm 49.0$ & $79.1 \pm 49.3$ & $65.3 \pm 34.7$ & $\mathrm{p}>0.05$ & $\mathrm{p}<0.01$ \\
\hline Orthophosphate $\left(\mu \mathrm{g} . \mathrm{L}^{-1}\right)$ & $12.0 \pm 9.7^{\mathrm{b}}$ & $16.3 \pm 15.3^{\mathrm{ab}}$ & $21.6 \pm 19.0^{\mathrm{a}}$ & $18.3 \pm 15.0^{\mathrm{ab}}$ & $\mathrm{p}<0.05$ & $\mathrm{p}<0.01$ \\
\hline Dissolved Oxygen (mg. $\left.\mathrm{L}^{-1}\right)$ & $3.3 \pm 0.6$ & $3.2 \pm 0.7$ & $3.2 \pm 0.6$ & $3.1 \pm 0.7$ & $\mathrm{p}>0.05$ & $\mathrm{p}<0.01$ \\
\hline Conductivity $\left(\mu \mathrm{S} . \mathrm{cm}^{-1}\right)$ & $41.3 \pm 1.7^{\mathrm{b}}$ & $41.8 \pm 1.8^{\mathrm{b}}$ & $41.8 \pm 1.1^{\mathrm{b}}$ & $42.7 \pm 1.8^{\mathrm{a}}$ & $\mathrm{p}<0.01$ & $\mathrm{p}<0.01$ \\
\hline TSS (mg.L $\left.\mathrm{L}^{-1}\right)$ & $15.4 \pm 11.5^{\mathrm{ab}}$ & $12.1 \pm 12.4^{\mathrm{b}}$ & $20.1 \pm 19.6^{\mathrm{a}}$ & $17.7 \pm 19.2^{\mathrm{a}}$ & $\mathrm{p}<0.05$ & $\mathrm{p}<0.01$ \\
\hline $\mathrm{pH}$ & $6.9 \pm 0.4$ & $7.0 \pm 0.6$ & $6.6 \pm 0.5$ & $6.6 \pm 0.7$ & $\mathrm{p}>0.05$ & $\mathrm{p}<0.01$ \\
\hline Temperature $\left({ }^{\circ} \mathrm{C}\right)$ & $25.8 \pm 3.0^{\mathrm{a}}$ & $25.4 \pm 2.8^{b}$ & $25.4 \pm 2.9^{b}$ & $25.7 \pm 2.7^{\mathrm{ab}}$ & $\mathrm{p}<0.05$ & $\mathrm{p}<0.01$ \\
\hline Chlorophyll- $a\left(\mu \mathrm{g} . \mathrm{L}^{-1}\right)$ & $30.4 \pm 35.3$ & $48.9 \pm 64.3$ & $41.9 \pm 24.8$ & $41.3 \pm 47.7$ & $\mathrm{p}>0.05$ & $\mathrm{p}<0.01$ \\
\hline Alkalinity $\left(\mathrm{mg} \cdot \mathrm{L}^{-1}\right)$ & $32.7 \pm 2.4$ & $32.5 \pm 3.5$ & $32.1 \pm 3.1$ & $32.0 \pm 3.6$ & $\mathrm{p}>0.05$ & $\mathrm{p}<0.01$ \\
\hline Bicarbonate (mg. $\mathrm{L}^{-1}$ ) & $39.6 \pm 2.7$ & $39.1 \pm 3.5$ & $39.2 \pm 3.8$ & $38.6 \pm 4.4$ & $\mathrm{p}>0.05$ & $\mathrm{p}<0.01$ \\
\hline $\mathrm{BOD}_{5}\left(\mathrm{mg} \cdot \mathrm{L}^{-1}\right)$ & $3.3 \pm 1.6$ & $3.8 \pm 1.1$ & $3.5 \pm 1.5$ & $3.1 \pm 1.5$ & $\mathrm{p}>0.05$ & $\mathrm{p}<0.01$ \\
\hline Hardness (mg. $\left.\mathrm{L}^{-1}\right)$ & $11.8 \pm 1.8^{\mathrm{b}}$ & $12.4 \pm 2.0^{\mathrm{b}}$ & $12.3 \pm 1.3^{\mathrm{b}}$ & $13.8 \pm 2.3^{\mathrm{a}}$ & $\mathrm{p}<0.01$ & $\mathrm{p}<0.01$ \\
\hline Water Transparency $(\mathrm{cm})$ & $130 \pm 20$ & $120 \pm 30$ & $110 \pm 40$ & $130 \pm 20$ & $\mathrm{p}>0.05$ & $\mathrm{p}<0.01$ \\
\hline $\mathrm{P}_{\text {sed. }}\left(\mu \mathrm{gP} \cdot \mathrm{g}^{-1}\right)$ & $0.4 \pm 0.1^{\mathrm{b}}$ & $0.3 \pm 0.1^{\mathrm{c}}$ & $0.5 \pm 0.1^{\mathrm{b}}$ & $0.7 \pm 0.3^{\mathrm{a}}$ & $\mathrm{p}<0.01$ & $\mathrm{p}>0.05$ \\
\hline $\mathrm{OM}_{\text {sed. }}(\%)$ & $3.1 \pm 0.6^{\mathrm{b}}$ & $3.9 \pm 0.7^{b}$ & $5.8 \pm 1.3^{\mathrm{a}}$ & $3.5 \pm 0.9^{b}$ & $\mathrm{p}<0.01$ & $\mathrm{p}>0.05$ \\
\hline
\end{tabular}



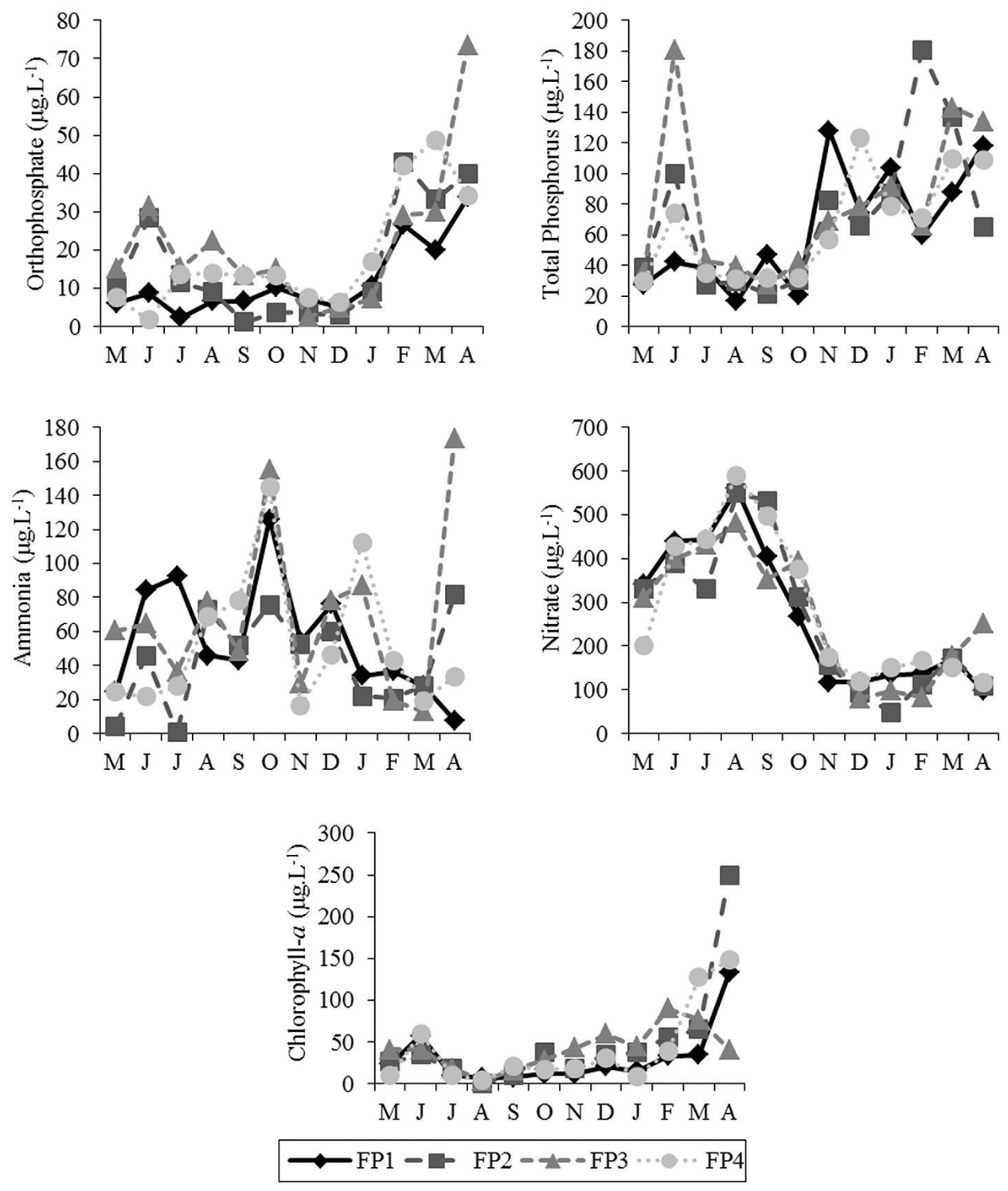

Figure 2. Monthly variation (mg. $\mathrm{L}^{-1}$ ) of orthophosphate, total phosphorus, ammonia, nitrate and chlorophyll- $a$ of the water samples in the fishponds (FP1 to FP4) during the study period.

and low chlorophyll- $a$ varying between 11 to $37 \mathrm{mg} . \mathrm{L}^{-1}$. The values obtained for dissolved oxygen indicated the low oxygenation in the water column, with a minimum of $1.3 \mathrm{mg} . \mathrm{L}^{-1}$ (FP2 and FP4) in October, and a maximum of $4 \mathrm{mg} \cdot \mathrm{L}^{-1}$ (FP1 and FP2) in May and April during the study period. The water $\mathrm{pH}$ is close to neutral, showing little variation throughout the year and no seasonal pattern. The same was observed to alkalinity and bicarbonate, showing low variation during the study period (Table 1; Figures 2 and 3 ).

The quantitative analysis of samples taken in the four fishponds revealed that the phytoplankton community was represented by a total of 30 taxa (species or genus). The Chlorophyceae and Zygnematophyceae, had highest richness, represented by 12 and 9 taxa respectively, followed by Bacillariophyceae with 6 taxa, as illustrated in Table 2. There were great changes in phytoplankton densities during the study period. The fishponds FP2 and FP3 had the largest number of constant species was observed. Cyanobacteria (Cylindrospermopsis sp.) and Zygnematophyceae (Staurastrum leptocladum) had one specie constant in the four fishponds, whereas Chlorophyceae and Bacillariophyceae was represented by six and three constant species in the four fishponds, respectively during the study period (Table 2).

High density of Cyanobacteria occurred at FP1, FP3 and FP4 during March, and the chlorophyll- $a$ contents were below 41 mg.L ${ }^{-1}$. In April when Cyanobacteria species were present but not abundant at FP1, FP2 and FP4, the chlorophyll- $a$ contents were above $133 \mathrm{mg} . \mathrm{L}^{-1}$, with the 

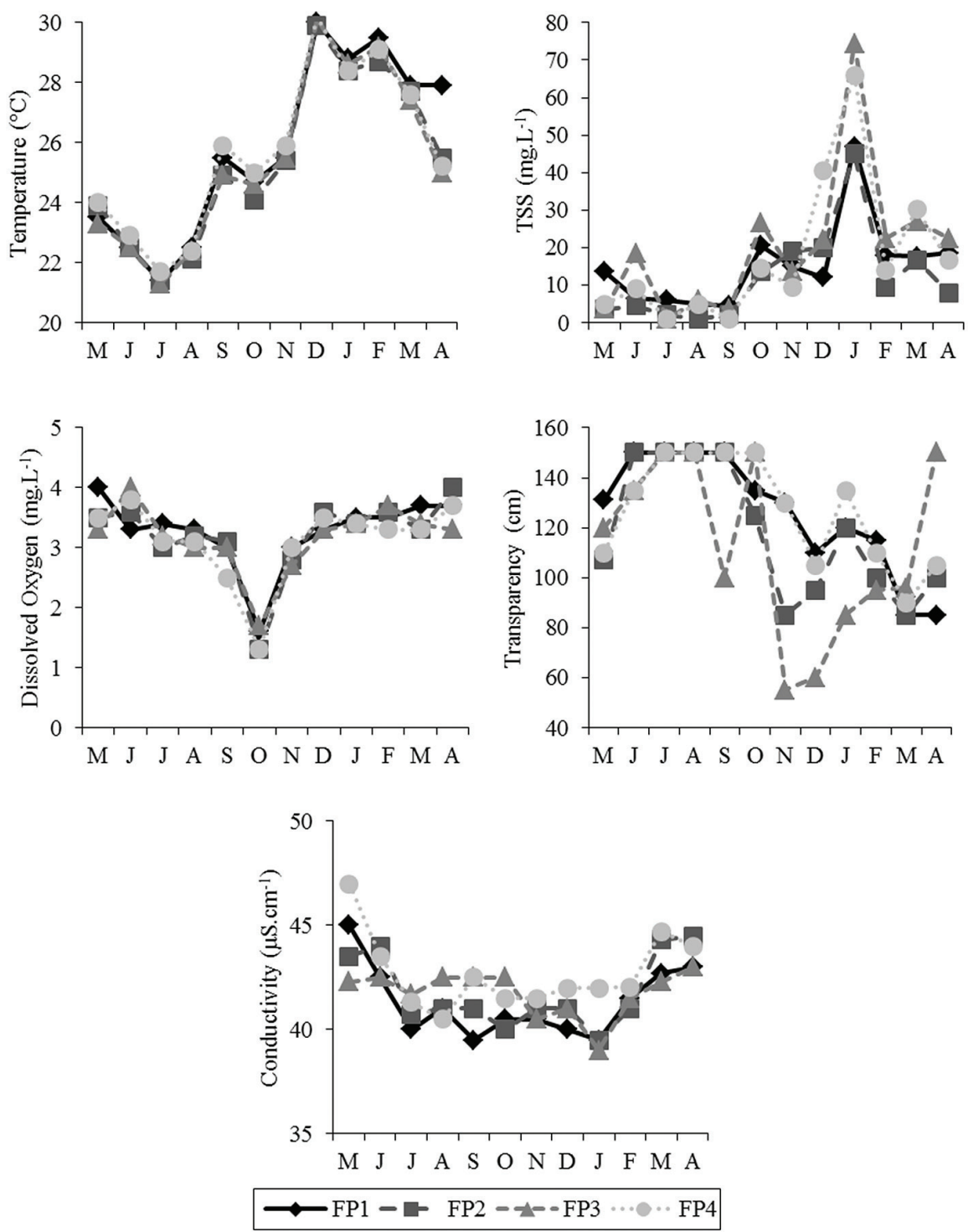

Figure 3. Monthly variation (mg. $\mathrm{L}^{-1}$ ) of temperature, TSS, dissolved oxygen, transparency and conductivity of the water samples in the fishponds (FP1 to FP4) during the study period.

exception of FP3 where Cyanobacteria was dominant $(>70 \%)$ and chlorophyll- $a$ was below $40 \mathrm{mg} . \mathrm{L}^{-1}$ (Table 1; Figures 2 and 3).

Bacillariophyceae were reported in all months, in general with highest abundance between August and October, but in FP1 was highest in October, November and January. In October orthophosphate and hardness concentrations decreased, and lowest dissolved oxygen $\left(<1.7 \mathrm{mg} . \mathrm{L}^{-1}\right)$ and $\mathrm{BOD}_{5}\left(<3.8 \mathrm{mg} \cdot \mathrm{L}^{-1}\right)$ concentrations were reported (Table 1; Figures 3 and 4).

Chlorophyceae had the highest abundance percentage, or rather, more than $46 \%$, between June and July in all fishponds, at FP1 they were dominant between July and September with $83 \%$ of total phytoplankton population, with an increase in nitrate concentrations and a decrease of orthophosphate concentrations (Figures 2 and 4).

Zygnematophyceae increased at higher abundance percentages in January (86\%) at FP2 with highest $\mathrm{pH}$ (7.8), low ammonia ( $\left.22 \mathrm{mg} . \mathrm{L}^{-1}\right)$ and nitrate $\left(49 \mathrm{mg} . \mathrm{L}^{-1}\right)$ contents. In November this group was represented with $72 \%$ and February with $69 \%$ at FP4, associated with highest conductivity $\left(41 \mathrm{mS} . \mathrm{cm}^{-1}\right)$ and hardness $\left(11 \mathrm{mg} . \mathrm{L}^{-1}\right)$ were reported (Table 1; Figures 2, 3 and 4).

Chrysophyceae, represented by Dinobryon sp. featuring $93 \%$ total of species in December and only occurred at FP1 in this month when observed highest temperature $\left(29^{\circ} \mathrm{C}\right)$ and low ammonia (76 mg. $\left.\mathrm{L}^{-1}\right), \mathrm{pH}(6.8)$, conductivity $\left(40 \mathrm{mS} \mathrm{cm}^{-1}\right)$ and TSS (12 mg.L $\left.\mathrm{L}^{-1}\right)$ were reported (Table 1; 
Table 2. Specific composition (SC), and frequency occurrence (F) of phytoplankton taxa in the four fishponds (FP1 to FP4), where: $+=$ presence; $-=$ absence; $\bullet=$ constant; $\mathrm{o}=$ common and $\phi=$ rare.

\begin{tabular}{|c|c|c|c|c|c|c|c|c|}
\hline \multirow{2}{*}{ TAXA } & \multicolumn{2}{|c|}{ FP1 } & \multicolumn{2}{|c|}{ FP2 } & \multicolumn{2}{|c|}{ FP3 } & \multicolumn{2}{|c|}{ FP4 } \\
\hline & SC & $\mathbf{F}$ & SC & $\mathbf{F}$ & SC & $\mathbf{F}$ & SC & $\mathbf{F}$ \\
\hline \multicolumn{9}{|l|}{ Bacillariophyceae } \\
\hline Epithemia sp. & + & ० & + & $\phi$ & + & $\phi$ & + & ○ \\
\hline Flagilaria sp. & - & - & - & - & + & $\circ$ & + & $\phi$ \\
\hline Melosira sp. & + & $\bullet$ & + & $\bullet$ & + & $\bullet$ & + & $\bullet$ \\
\hline Navicula sp. & + & $\bullet$ & + & $\bullet$ & + & $\bullet$ & + & $\bullet$ \\
\hline Pinnularia sp. & + & $\phi$ & + & $\circ$ & + & $\circ$ & + & ○ \\
\hline Surirella sp. & + & $\bullet$ & + & $\bullet$ & + & $\bullet$ & + & $\bullet$ \\
\hline \multicolumn{9}{|l|}{ Chlorophyceae } \\
\hline Ankistrodesmus falcatus (Corda) Ralfs & + & $\bullet$ & + & $\bullet$ & + & $\bullet$ & + & $\bullet$ \\
\hline Chlorella vulgaris (Kesser \& Huss) & + & $\bullet$ & + & $\bullet$ & + & $\bullet$ & + & $\bullet$ \\
\hline Coelastrum reticulatum (Dangeard) Senn & + & $\bullet$ & + & $\bullet$ & + & $\bullet$ & + & $\bullet$ \\
\hline Crucigena sp. & + & $\circ$ & + & $\circ$ & + & $\circ$ & + & $\circ$ \\
\hline Gloeocytis vesiculosa (Nägeli) & + & $\circ$ & + & ○ & - & - & - & - \\
\hline Oocystis sp. & + & $\bullet$ & + & $\bullet$ & + & $\bullet$ & + & $\bullet$ \\
\hline Pediastrum duplex (Meyen) & + & $\bullet$ & + & $\bullet$ & + & $\bullet$ & + & $\bullet$ \\
\hline Scenedesmus sp. & + & $\circ$ & + & $\bullet$ & + & $\bullet$ & + & $\circ$ \\
\hline Scenedesmus acuminatus (Largerheim) Chodat & + & ○ & + & $\phi$ & + & $\circ$ & + & $\circ$ \\
\hline Scenedesmus quadricauda (Turpin) Brébison & + & $\bullet$ & + & $\bullet$ & + & $\bullet$ & + & $\bullet$ \\
\hline Tetraspora sp. & - & - & + & $\circ$ & + & $\phi$ & + & $\circ$ \\
\hline \multicolumn{9}{|l|}{ Chrysophyceae } \\
\hline Dinobryon sp. & + & $\phi$ & - & - & - & - & - & - \\
\hline \multicolumn{9}{|l|}{ Cyanobacteria } \\
\hline Cylindrospermopsis sp. & + & $\circ$ & + & ० & + & $\circ$ & + & $\phi$ \\
\hline Microcystis sp. & + & $\bullet$ & + & $\bullet$ & + & $\bullet$ & + & $\bullet$ \\
\hline Rhabdoderma sp. & + & ○ & + & $\circ$ & + & $\bullet$ & + & $\circ$ \\
\hline \multicolumn{9}{|l|}{ Zygnematophyceae } \\
\hline Closterium sp. & + & ० & + & $\bullet$ & + & ० & + & $\circ$ \\
\hline Cosmarium sp. & + & $\bullet$ & + & $\bullet$ & + & $\bullet$ & + & $\circ$ \\
\hline Euastrum sp. & + & $\phi$ & - & - & - & - & - & - \\
\hline Micrasterias sp. & + & $\phi$ & + & $\phi$ & + & $\phi$ & + & $\phi$ \\
\hline Mougeotia sp. & + & ○ & + & $\circ$ & + & $\bullet$ & + & $\circ$ \\
\hline Spirogyra sp. & + & ० & + & $\circ$ & + & $\bullet$ & + & $\circ$ \\
\hline Spondylosium sp. & + & $\phi$ & - & - & - & - & + & $\phi$ \\
\hline Staurastrum leptocladum Ralfs & + & $\bullet$ & + & $\bullet$ & + & $\bullet$ & + & $\bullet$ \\
\hline Staurodesmus sp. & + & $\bullet$ & + & $\bullet$ & + & $\circ$ & + & $\circ$ \\
\hline
\end{tabular}

Figures 2, 3 and 4). The highest TSS values ranging between 45 and $75 \mathrm{mg} . \mathrm{L}^{-1}$, were observed in the four fishponds in January (Table 1; Figures 2, 3 and 4).

Similarity analyses for phytoplankton densities showed the formation of two groups, FP2 fishpond was markedly different from the others ponds with regard to phytoplankton (Figure 5).

Sediment phosphorus contents varied between 0.33 and $0.76 \mathrm{mg} . \mathrm{L}^{-1}$, with low contents throughout the whole period under analysis. High rates of organic matter were reported at fishpond FP3, varying between $2.8 \%$ and $8.8 \%$. Phosphorus and organic matter in the sediment did not vary $(p>0.05)$ between months but were significantly different $(\mathrm{p}<0.01)$ among the fishponds (Table 1).

\section{Discussion}

Results show that difference $(\mathrm{p}<0.05)$ existed among fishponds with regard to orthophosphate, conductivity, TSS, temperature and hardness even though some limnological variables differed throughout the period analyzed and thus interfered directly with the phytoplankton community. The fishponds are shallow, turbid and warm neotropical ponds. The water has $\mathrm{pH}$ nearly neutral, low oxygenation and conductivity during the year. Total suspended solids concentrations increase considerably during December and January (rainy period) probably as a consequence of allochthonous material (organic and inorganic) of water supply and fertilize management (fish grow-out period). 


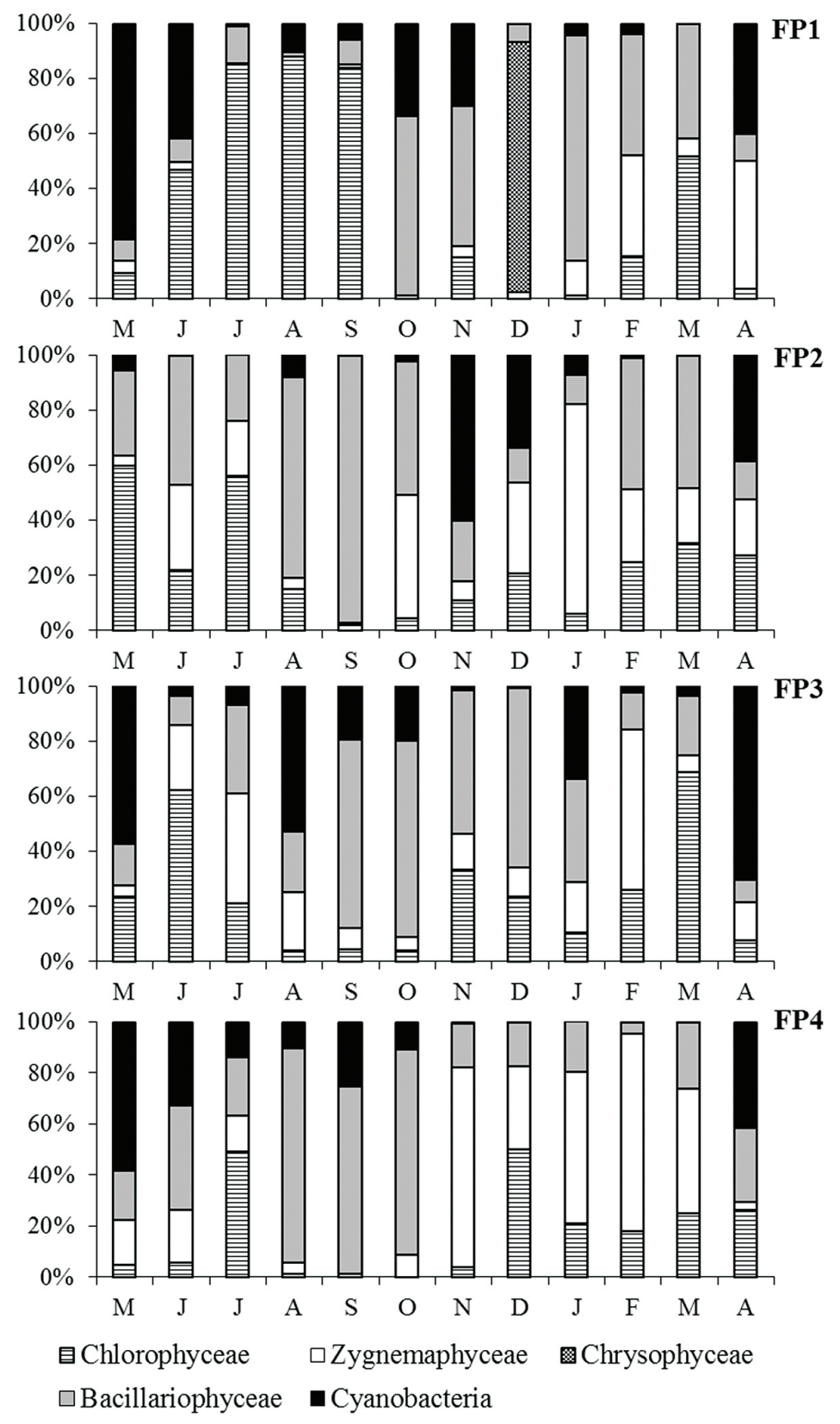

Figure 4. Relative abundance (\%) of phytoplankton groups in the fishponds (FP1 to FP4) during the studied period.

This is also a possible explanation for the high total phosphorus, orthophosphate and chlorophyll- $a$ contents and low nitrate concentration during this period.

The phytoplankton community of the four fishponds was represented in the samples by numerous genus and species among Chlorophyceae and Zygnematophyceae, but Bacillariophyceae and Chlorophyceae were found to be the most frequent in the fishponds during the study period, followed by Zygnematophyceae and Cyanobacteria. High frequency of Bacillariophyceae is attributed moderate levels of nutrients, low conductivity waters and high transparency (Baba et al., 2011), as reported in current study.
The growth and abundance of Chlorophyceae in the present study also reflect the oligo-mesotrophic nature of the fishponds water. Chlorophyceae species in these fishponds in general they are more dominant groups in terms of species number due to temperature and nutrients contents (Sipaúba-Tavares et al., 2011).

Human activities in the fishponds introduce allochthonous material, which may affect the physical and chemical variables from one season to another (Davies et al., 2009). Since seasonal variations affect the physical and chemical variables, there are variation in plankton abundance and diversity. Intense feed management (high feed addition in 


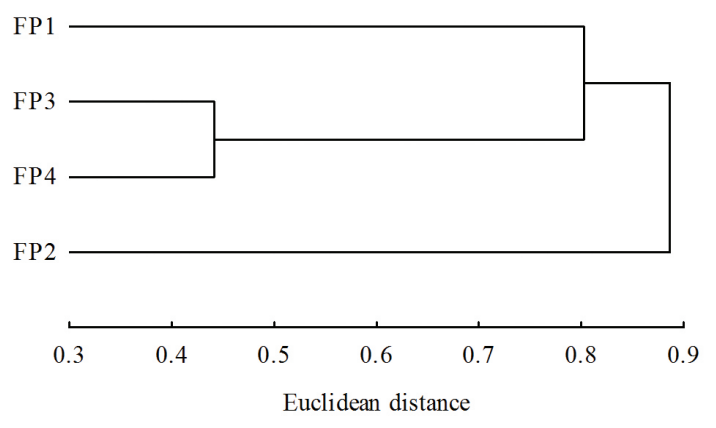

Figure 5. Cluster analysis considering the average total densities of phytoplankton (ind. $\mathrm{m}^{3} \times 10^{3}$ ) at the four fishponds. Abundance data were transformed to $\log _{10}(x+1)$.

ponds) during the summer (rainy season, from November to March) increased chlorophyll- $a$, TSS, orthophosphate and total phosphorus contents, low nitrate and conductivity, with high density of Zygnematophyceae in FP4 and FP2 (January). In generally, Zygnematophyceae is found mainly in nutrient-poor acidic water environments with low electrical conductivity and high transparency (Felisberto and Rodrigues, 2005).

The highest Cyanobacteria densities have been found in March and April in FP1, FP3 and FP4, with low temperature and high conductivity values were reported.

Chrysophyceae represented $91.5 \%$ of total phytoplankton only in December (FP1), and none during the rest of the studied period. Chrysophyceae were represented just one species, namely, Dinobryon sp. This species may grow in the phytoplankton of both acid and base waters, characterized by poor nutrients, alkalinity and high tolerance to low temperatures. It is a highly common species causing blooms in oligo-mesotrophic ponds during the summer (Tas et al., 2010). The ability of flagellates to overcome low nutrients affinity by complementing the diet inorganic nutrients with organic ones is well-known survival strategy in this microalgae group (Loureiro et al., 2009).

Dissolved oxygen concentrations in fishponds were low varied between 1.3 and $4.0 \mathrm{mg} . \mathrm{L}^{-1}$. In fact, a sharp decrease in dissolved oxygen concentrations occurred in all fishponds in October. This fact coincided with high ammonia contents varying between 76 and $156 \mathrm{mg} . \mathrm{L}^{-1}$. Ammonia contents are usually low in oxygenated waters of mesotrophic ponds due to its use by algae in the photic zone and nitrification to nitrogen oxidized forms (Quirós, 2003).

Nitrate concentrations became low between November and April and $\mathrm{pH}$ varied between 6.5 and 7.9, whereas organic matter was high mainly in FP3. The removal of nitrogen from waters is usually dominated by nitrate denitrification, concomitantly with the oxidation of organic matter. However, highly productive surface waters with high $\mathrm{pH}$ would favor nitrogen release to the atmosphere as ammonia (Quirós, 2003).

Low nitrogen compounds in the fishponds caused in low chlorophyll- $a$ contents in present study, with values below 100 mg.L ${ }^{-1}$, except in March with 127 mg.L ${ }^{-1}$ at
FP1 and in April at FP1 (132 mg.L $\left.{ }^{-1}\right)$, FP2 (250 mg.L $\left.{ }^{-1}\right)$ and FP4 (148 mg. $\left.\mathrm{L}^{-1}\right)$. The concentration of chlorophyll- $a$ in algal cells declines under nitrogen limitation, because nitrogen is a major constituent of this pigment and its apoprotein (Heraud et al., 2007).

A high load of organic matter (dead algal cell, fish feed solids, uneaten food) in bottom sediments is related to the fishpond fertilization management featuring plankton densities, high quantities of non-consumed remains and consequently large metabolites produced by fish, mainly in the fish grow-out period during the rainy and hot season. In fact, occurs an increase in fish waste and, consequently, with a higher nitrogen and phosphorus release through feces and urine. Thus, an increase of nutrients in the water and sediment occurred during this period.

Ammonia nitrogen is the most important and readily available nitrogen source for phytoplankton. In the current study, ammonia concentrations were lower than $145 \mathrm{mg} . \mathrm{L}^{-1}$ (except FP3 in October with 155 mg. $\mathrm{L}^{-1}$, and March with $173 \mathrm{mg} . \mathrm{L}^{-1}$ ), probably due to the fast ammonia uptake by phytoplankton. The relatively low ammonia during the study period may be attributed the competitive advantage for Cyanobacteria, mainly in May and April, due to high affinity ammonium uptake. Since nitrogen and phosphorus are commonly found in fertilizers used in fishponds and relatively high temperature are favorable conditions for the growth of Cyanobacteria. This taxon is dominant at temperatures above $20^{\circ} \mathrm{C}$, alkaline $\mathrm{pH}$ and high nutrient concentration (Rahman and Jewel, 2008).

According to cluster the fishpond FP2 exhibited the highest difference when compared to others ponds. Such difference may be associated with low density of Cyanobacteria, except in November, and high dominance of Bacillariophyceae during the study period.

Great care should be taken in feeding management since high ammonia concentrations associated with high $\mathrm{pH}$ and temperature cause higher abundance of Cyanobacteria, mainly after the fish grow-out period (April). During the study period, several materials (diet and fertilizers) were added to the fishponds. These materials produced in the pond (feces, urine, nitrification) can be retained in the sediment and later released in the water column. This fact occurred in April when phytoplankton groups had excellent representations and high concentrations of nutrients (mainly ammonia and orthophosphate) in the water column and phosphorus and organic matter (mainly FP3 and FP4) in the sediment.

Succession changes in biotic and abiotic parameters are associated with many factors, like food management, human activities, hydraulic retention time, climatic factors, fish density, and others intrinsic factors that affect abiotic parameters in the fishponds. Since there are many extrinsic and intrinsic factors associated with limnological variables, these factors would have a weighted effect related to the particular characteristics of fishponds. Results of current study showed that some limnological variables vary among fishponds and during the year (May-April).

The physical and chemical parameters of fishponds water constituted relations between the parameters and 
algae occurrence. The fishponds under analysis feature high density of Chlorophyceae and Bacillariophyceae mainly June to January. Cyanobacteria had high density mainly in April (mainly FP3) when total phosphorus, orthophosphate and ammonia contents were high. The present study however, indicated that Cyanobacteria were more frequent in the fishponds after the fish grow-out period and the water quality should be monitored more frequently in this period due to the high total phosphorus, orthophosphate and chlorophyll- $a$ contents. Water management within these fishponds may be optimized to avoid risks associated with Cyanobacteria and impairment to the water uses, due the effluents of these fishponds directly discharged into the largest pond.

Acknowledgements - The authors would like to thank the Brazilian Council for Scientific and Technological Development (CNPq) for financial support. We would also like the working group of Limnology and Plankton Production Laboratory of CAUNESP.

\section{References}

ANDERSEN, JM., 1976. An ignition method for determination of total phosphorus in lake sediments. Water Research, vol. 10, no. 4, p. 329-331. http://dx.doi.org/10.1016/0043-1354(76)90175-5

AMERICAN PUBLIC HEALTH ASSOCIATION - APHA, 1998. Standard methods for the examination of water and wastewater. 20th ed. Washington: American Public Health Association, America Water Works Association, Water Environmental Federation.

BABA, AI., SOFI, AH., BHAT, SU. and PANDIT, AK., 2011. Periphytic algae of river Sindh in the Sonamargarea of Kashmin valley. Journal of Phytology, vol. 3, no. 6, p. 1-12.

BOYD, CE. and TUCKER, CS., 1992. Water quality and pond soil analyses for aquaculture. Auburn: Alabama Agricultural Experiment Station, Auburn Univeristy. 183 p.

DAVIES, OA., ABOWEI, J F.N. and OTENE, B.B., 2009. Seasonal abundance and distribution of plankton of Minichinda stream, Niger Delta, Nigeria. America of Journal Science Research, vol. 2 , no. 2 , p. 20-30.

FELISBERTO, AS. and RODRIGUES, L., 2005. Influência do gradiente longitudinal (rio-barragem) na similaridade das comunidades de desmídias perifíticas. Revista Brasileira de Botânica, vol. 28, no. 2, p. 241-254.

GOLTERMAN, HL., CLYMO, RS. and OHNSTAD, MAM., 1978. Methods for physical and chemical analysis of freshwater. 2nd ed. Oxford: Blackwell Scientific Publication. 213 p. IBP Handbook, no. 8.

HERAUD, P., BEARDALL, J., MCNAUGHTON, D. and WOOD, BR., 2007. In vivo prediction of the nutrient status of individual microalgal cells using Raman microspectroscopy. Research Letters, vol. 275 , no. 1 , p. 24-30

KOPP, R., VITEK, T., STASTNY, J., SUKOP, I., BRABEC, T., ZIKOVA, A., SPURNY, P. and MARES, J., 2012. Water quality and biotic community of a highland stream under the influence of a eutrophic fishpond. International Review of Hydrobiology, vol. 97, no. 1, p. 26-40. http://dx.doi.org/10.1002/iroh.201111426

KOROLEFF, F., 1976. Determination of nutrients. In GRASHOF, E. and KREMLING, E. (Eds.). Methods of sea water analysis. German: Verlag Chemie Wenhein. p. 126-133.
LOUREIRO, S., JAUZEIN, C., GACÉS, E., COLLOS, Y., CAMP, J. and VAQUÉ, D., 2009. The significance of organic nutrients in the nutrition of Pseudo-nitzschia delicatissima (Bacillariophyceae). Journal of Plankton Research, vol. 31, no. 4, p. 399-410. http:// dx.doi.org/10.1093/plankt/fbn122

LUND, JWG., KIPLING, C. and LE CREN, ED., 1958. The inverted microscopic method of estimating algal numbers and the statistical basis of estimations by counting. Hydrobiologia, vol. 12, p. 143-170.

MACKERETH, FJH., HERON, J. and TALLING, FJ., 1978. Water analysis: some revised methods for limnologists. England: Titus Wilson and Son. $124 \mathrm{p}$

MAGURRAN, AE., 1989. Diversidad ecológica y su medición. Barcelona: Ediciones Vedrá. 200 p.

NEOFITOU, N. and KLAOUDATOS, S., 2008. Effect of fish farming on the water column nutrient concentration in a semi-enclosed gulf of the Eastern Mediterranean. Aquaculture Research, vol. 39, no. 5, p. 482-490. http://dx.doi.org/10.1111/j.1365-2109.2008.01900.x

NUSCH, EA., 1980. Comparison of different methods for chorophyll and phaeopigments determination. Archives für Hydrobiologie, vol. 14, p. 14-36.

QUIRÓS, R., 2003. The relationship between nitrate and ammonia concentrations in the pelagic zones of lakes. Limnética, vol. 22, no. $1-2$, p. $37-50$.

RAHMAN, MM. and JEWEL, MAS., 2008. Cyanobacterial blooms and water quality in two urban fish ponds. University Journal of Zoology, Rajshahi University, vol. 27, p. 79-84.

SAMPAIO, EV., ROCHA, O., MATSUMURA-TUNDISI, T. and TUNDISI, JG., 2002. Composition and abundance of zooplankton in the limnetic zone of seven reservoirs of the Paranapanema River, Brazil. Brazilian Journal of Biology, vol. 6, no. 3, p. 525-545.

SIPAÚBA-TAVARES, LH., LOURENÇO, E.M. and BRAGA, F.M.S., 2010. Water quality in six sequentially disposed fish ponds with continuous water flow. Acta Scientiarum Biological Sciences, vol. 32, no. 1, p. 9-15. http://dx.doi.org/10.4025/ actascibiolsci.v32i1.3436

SIPAÚBA-TAVARES, LH., DONADON, A.R.V. and MILLAN, R.N., 2011. Water quality and plankton populations in an earthen polyculture pond. Brazilian Journal of Biology, vol. 71, no. 4, p. 1-11.

STATSOFT INC., 2007. STATISTICA (Data Analysis Software System), version 8. Available from: $<$ http:www.statsoft.com $>$.

TAS, B., GÖNÜLOL, A. and TAS, E., 2010. Seasonal dynamics and biomass of mixotrophic flagellate Dinobryon sertularia Ehrenberg (Chrysophyceae) in Derbent reservoir (Samsun, Turkey). Turkish Journal of Fisheries and Aquatic Science, vol. 10 , no. 3, p. 305-313.

VEGA, C., JAMBRINA, C., SAJA, R., BECARES, E., FERNÁNDEZ, C. and FERNÁNDEZ, M., 2007. Aspectos limnológicos de estanques para la producción intensiva de tenca (Tirica tinca). Limnética, vol. 26, no. 1, p. 173-182.

ZHONG, F., GAO, Y., YU, T., ZHANG, Y., XU, D., XIAO, E., HE, F., ZHOU, Q. and WU, Z., 2011. The management of undesirable cyanobacteria blooms in channel catfish ponds using a constructed wetland: Contribution to the control of off-flavor occurrences. Water Research, vol. 45, no. 19, p. 6479-6488. PMid:22000715. http://dx.doi.org/10.1016/j.watres.2011.09.044 